\title{
Perspectives and predictions on the microbial ecology of the hyporheic zone
}

\author{
R. G. STOREY*, R. R. FULTHORPE† AND D. D. WILLIAMS* \\ *Division of Life Sciences; †Division of Physical Sciences, University of Toronto at Scarborough, 1265 Military Trail, \\ Scarborough, Ontario, M1C 1A4, Canada
}

\section{SUMMARY}

1. Studies of hyporheic microbial ecology have suggested an important role for hyporheic microbial processes in stream ecosystem functioning. Using evidence from microbial communities in other aquatic habitats, some predictions are made concerning the diversity of microbial types and microbial processes likely to occur in the hyporheic zone, and the relative importance of these various types to the hyporheic ecosystem.

2. It is predicted that the biofilm growth form of interstitial micro-organisms will create a variety of microniches, allowing coexistence of a great diversity of microbial types, and promoting the activity of some otherwise poor competitors. It is further predicted that the confluence of reduced groundwaters and aerobic surface waters will favour chemolithotrophic processes in the hyporheic zone, but that these will contribute significantly to hyporheic production only if surface water is very low in dissolved organic carbon, or the groundwater is extremely reduced, such as by the influence of riparian wetlands. A variety of anaerobic respiratory pathways, such as nitrate, ferric ion, sulphate and even methanogenic respiration will be employed in the hyporheic zone, with biofilm dynamics permitting these to occur even in aerobic sediments. Anaerobic pathways may account for a significant proportion of total hyporheic organic matter mineralization.

3. The role of fungi in hyporheic dynamics is, as yet, almost completely unstudied. However, it is expected that they will be important in breaking down buried particulate organic matter (POM), which may account for a large proportion of total stream POM.

4. Physicochemical conditions in hyporheic sediments appear to be highly heterogeneous, and this heterogeneity may be very important in the cycling of certain nutrients, especially nitrogen, which involves a series of steps requiring different conditions.

5. Various new techniques are now available by which biofilm dynamics and in situ microbial processes may be measured. Studies are recommended of intact microbial communities both at the microscale of the biofilm and at the scale of the heterogeneities occurring in hyporheic sediments. Studies are needed that measure actual rates of microbial processes under in situ conditions.

Keywords: hyporheic zone, microbial ecology, biofilm, chemolithotrophy, anaerobic fungi, bacteria

Correspondence: Richard G. Storey, Division of Life Sciences, University of Toronto at Scarborough, 1265 Military Trail, Scarborough, Ontario, M1C 1A4, Canada.

E-mail: storey@scar.utoronto.ca

\section{Introduction}

Over the past two decades, the hyporheic zone has become recognized as a site of high biological activity, and the importance of hyporheic processes in stream ecosystem functioning has begun to be appreciated. 
The hyporheic zone can be an important sink (Grimm \& Fisher, 1984) or source (Fiebig \& Lock, 1991) of energy for the stream ecosystem. It can act as a buffer between groundwater sources and the surface stream by storing and transforming inflowing nutrients (Triska et al., 1994), and is an important site for remineralization of organic matter in surface waters, releasing bound nutrients for surface productivity (Jones, Fisher \& Grimm, 1995a). Hyporheic microorganisms also can provide an important food source for meiofauna (Barlocher \& Murdoch, 1989), many of which migrate between surface and subsurface habitats (Williams \& Hynes, 1974).

While it is acknowledged that determining microbial processes is essential to developing an understanding of hyporheic ecology and its contribution to the stream ecosystem (e.g. Brunke \& Gonser, 1997), very few researchers of the hyporheic zone have studied micro-organisms directly, and only a few types of microbial process have been investigated. On the other hand, microbial ecologists studying aquatic sediments have focused mainly on streambed surfaces, and sediments of lakes and marine systems; they have given much less attention to applying their techniques or extending their conclusions to describe the hyporheic zone, with its particular dynamics and combination of habitat characteristics.

Hyporheic investigations to date have provided some valuable insights. Grimm \& Fisher (1984) and Pusch \& Schwoerbel (1994) have shown that the hyporheic zone supports high rates of respiration, which can equal those at the surface on an areal basis, and of which up to $96 \%$ can be attributed to organisms less than $100 \mu \mathrm{m}$ in size. Triska, Duff \& Avanzino (1993a) and McClain, Richey \& Pimentel (1994) have shown that nitrification and denitrification processes alter the predominant form of nitrogen occurring in different parts of the hyporheic zone, and can significantly alter amounts of total inorganic nitrogen. Fiebig \& Lock (1991) and Findlay et al. (1993) have demonstrated rapid uptake of dissolved organic matter (DOM) in groundwater and surface water as these pass through the hyporheic zone, and Hendricks (1993) has shown that areas where surface water downwells have higher bacterial densities and productivity than those where groundwater upwells.

However, many crucial questions concerning the microbial ecology of the hyporheic zone have only just begun to be addressed in field studies. What is the full range of microbial types and microbial processes likely to occur in the hyporheic zone? What are the relative abundances of these types and the relative importance of these processes? How are they distributed within the hyporheic zone, and how do they interact with each other and with surface processes? In what ways will hyporheic microbial processes differ among different stream systems, and what factors will cause these differences? As yet only one or two field studies have investigated these questions. In an attempt to catalyse more such work this paper makes some predictions on what microbial types and processes are possible in the hyporheic zone by combining a knowledge of typical habitat conditions occurring in this zone with the findings of microbial field studies in various other aquatic environments. The responses of micro-organisms to gradients in nutrients, electron donors and electron acceptors have been well established through these other aquatic studies, and they should operate in the same way in the hyporheic zone.

Once the microbial processes operating in the hyporheic zone have been described on this level, it should be possible to determine their importance on an ecosystem level. Readers are referred to Findlay (1995) and Harvey \& Fuller (1998), who used hydrologic measures - the proportion of stream discharge passing through the hyporheic zone and residence time of that water in the hyporheic zoneto predict the importance of hyporheic zone processes in the stream ecosystem.

Finally, some new techniques in microbial ecology are highlighted, which have opened new possibilities for hyporheic microbial research.

\section{Bacterial types and processes possible in the hyporheic zone}

From a stream ecosystem perspective, the most useful way to consider the diversity of bacterial types is in terms of functional groups - organisms that perform a particular process such as converting ammonium to nitrate. Functional diversity amongst bacteria results from their ability to use compounds other than organic carbon as an energy source (chemolithotrophy) and compounds other than oxygen as an electron acceptor (anaerobic respiration). Bacteria show a wide diversity in these two aspects, which results in the 
wide range of biogeochemical processes found in natural environments.

Inorganic sources of energy

Inorganic energy sources are always reduced compounds, and are almost always metabolized aerobically. Thus chemolithotrophy occurs primarily at the interface of a reduced environment and an oxidizing one (Codd \& Kuenen, 1987). The hyporheic zone often is such an interface, frequently receiving reduced groundwaters from below and oxidizing surface waters from above, and in these cases would be expected to be an ideal environment for chemolithotrophic bacteria. Nitrification, the conversion of ammonium (via nitrite) to nitrate, is the main chemolithotrophic process to be described so far in field studies in the hyporheic zone, and these studies have shown that nitrification is an important process in hyporheic nitrogen dynamics, shifting the predominant form of inorganic nitrogen in incoming waters from ammonium to nitrate (Triska et al., 1993a; McClain et al., 1994). However, to date there has been only one study (Jones et al., 1994) comparing the productivity of hyporheic nitrifiers to that of hyporheic heterotrophs, and none comparing their abundance or their influence on other habitat parameters such as oxygen.

Nitrifying bacteria generally are in low abundance compared with heterotrophs. To produce $1 \mathrm{~g}$ of biomass, nitrifiers require $\approx 30 \mathrm{~g}$ of ammonia, whereas heterotrophs require only $2 \mathrm{~g}$ of glucose, and the doubling times of nitrifiers are roughly ten times as long (Stolp, 1993). Because, in unpolluted streams, waters entering the hyporheic zone will typically have dissolved organic carbon (DOC) concentrations of $1-20 \mathrm{mg} \mathrm{L}^{-1}$ (average $5.75 \mathrm{mg} \mathrm{L}^{-1}$ ) (Meybeck, 1982), compared with typical ammonium concentrations of only < 0.01-0.8 $\mathrm{mg} \mathrm{L}^{-1}$ (Hill, 1990; Triska et al., 1993a; McClain et al., 1994), primary production via nitrification in most pristine hyporheic zones would be expected to be insignificant compared with heterotrophic production. This was true in the desert stream investigated by Jones et al. (1994), where chemoautotrophic production was only $1.0-1.3 \%$ of total production, and only $6-29 \%$ of this was via nitrification. However, the proportion of the DOC pool that is available to microbial uptake is still not well known (Kaplan \& Newbold, 1993), having been estimated to range from $25 \%$ to less than $1 \%$ (Moss, 1988; Volk, Volk \& Kaplan, 1997); furthermore, the less labile fractions of the DOC pool may yield a significantly lower net energy gain than glucose, from which the energy yield comparisons were made. Therefore, in streams with very low instream DOC, or those receiving high nitrogen inputs from agricultural catchments, production via nitrification may be significant. Where this is true, the groundwater would represent an energy source to the stream ecosystem.

Nitrifiers are likely to be more abundant than is predicted from the concentration of ammonium in interstitial waters. In many stream systems, decomposition of organic nitrogen is probably a more important source of ammonium than groundwater supply (e.g. Jones et al., 1995a), and this ammonium may be released and nitrified entirely within biofilms, which colonize particulate organic matter (POM) and trap dissolved organics on inorganic particles (Paerl \& Pinckney, 1996).

Nitrifiers also can have a significant effect on hyporheic oxygen dynamics, even where their abundances and productivity are a small fraction of the total bacterial community. Oxidizing $1 \mathrm{~mol} \mathrm{ammo-}$ nium yields only 0.006 times as much energy as oxidizing $1 \mathrm{~mol}$ glucose (Stolp, 1993), but requires two-thirds the amount of oxygen (Stepanauskas, Davidsson \& Leonardson, 1996); thus even where the productivity of nitrifiers is 100 times less than that of the heterotrophs, they still may account for $50 \%$ of the total oxygen consumption. Kaushik et al. (1981) verified that nitrification can account for a significant proportion of biological oxygen demand (BOD) in unpolluted stream systems.

Apart from ammonium, bacteria are able to use $\mathrm{Fe}^{2+}$ and $\mathrm{Mn}^{2+}$ ions, reduced sulphur compounds $\left(\mathrm{S}^{0}\right.$, $\mathrm{S}_{2} \mathrm{O}_{3}{ }^{2-}, \mathrm{S}^{2-}$ ) or $\mathrm{H}_{2}$ as their sole energy source. In noting that nitrification accounted for only $6-29 \%$ of chemolithotrophic production in oxygenated hyporheic sediments of a desert stream, Jones et al. (1994) implied that one or more of these other chemicals were important energy sources for chemolithotrophic production in this stream. However, they did not measure any other forms of aerobic chemolithotrophy, only anaerobic $\mathrm{H}_{2}$ oxidation (methanogenesis), which occurred almost entirely in anoxic sediments; in other studies, only $\mathrm{Fe}^{2+}$ and $\mathrm{Mn}^{2+}$ oxidation have been reported in hyporheic sediments (Wielinga et al., 
1994; Harvey \& Fuller, 1998) and in these there was no attempt to measure production.

One major constituent of groundwaters is $\mathrm{Fe}^{2+}$, which occurs typically in concentrations of $0.1-$ $10 \mathrm{mg} \mathrm{L}^{-1}$, but occasionally up to $50 \mathrm{mg} \mathrm{L}^{-1}$, where conditions are sufficiently reducing (Hem, 1989). Eighteen genera of iron-oxidizing bacteria are ubiquitous in wells, springs and wetlands, producing characteristic orange encrustations (Hackett \& Lehr, 1985), and would therefore be expected to occur also in hyporheic zones receiving reduced groundwater. Where iron-bearing groundwaters encounter aerobic conditions, iron hydroxides will precipitate abiotically, but where oxygen concentrations are only 1$3 \mathrm{mg} \mathrm{L}^{-1}$, redox potentials are $200-350 \mathrm{mV}$ and the $\mathrm{pH}$ is slightly acidic ( $\mathrm{pH}$ 6.0-7.6), bacterial oxidation is favoured (Hackett \& Lehr, 1985). Such conditions are characteristic of hyporheic zones. However, the balance of $\mathrm{pH}$ and redox potential appears to be critical; Wielinga et al. (1994) found precipitation of iron oxides occurring throughout the hyporheic zone of a stream receiving acid mine drainage, but attributed this to abiotic oxidation, based on theoretical $\mathrm{pH} /$ Eh diagrams for iron.

By contrast, manganese oxidation in this stream was believed to be bacterially mediated, and $\mathrm{Mn}^{2+}$ oxidizing bacteria were found to make up a significant proportion of the total culturable bacteria in the hyporheic zone (Wielinga et al., 1994). However, in natural waters $\mathrm{Mn}^{2+}$ occurs in low concentrations (typically around $15 \mu \mathrm{g} \mathrm{L}{ }^{-1}$; Langmuir, 1997), thus manganese-oxidizers are expected to be abundant only where unusually high concentrations occur, such as at acid mine sites.

Iron and manganese oxidation both yield even less energy than ammonium oxidation (Brock, Smith \& Madigan, 1984; Hackett \& Lehr, 1985); furthermore, since many iron- and manganese-oxidizing bacteria are heterotrophic or mixotrophic, it remains unclear how much energy the bacteria actually gain from oxidation of the metal ions (Ghiorse, 1984). Therefore, although iron- and manganese-oxidizers in some places may be abundant and even produce visible deposits of metal hydroxides, $\mathrm{Mn}^{2+}$ and $\mathrm{Fe}^{2+}$ ions are not expected to contribute significantly to hyporheic productivity, except possibly where organic concentrations are very low and metal concentrations high. However, iron- and manganese-oxidizers still may affect the oxygen balance of hyporheic sediments, and the precipitates they produce could greatly impede interstitial water flows.

The importance of reduced inorganic compounds, such as iron, to hyporheic productivity will depend greatly on the redox state of the groundwater feeding the hyporheic zone. Shallow groundwaters are often oxidizing, having measurable dissolved oxygen concentrations of up to $4 \mathrm{mg} \mathrm{L}^{-1}$ or more (e.g. Hill, 1990; McClain et al., 1994), whereas deep, old groundwaters are generally more reduced, often with no free oxygen and redox potentials near or even below zero (Drever, 1982). Hill (1990) observed a difference in redox potential, and hence concentrations of reduced compounds, between deep and shallow groundwaters entering a hyporheic zone. Groundwaters influenced by high rates of organic matter decomposition can become highly reducing; many streams are bordered by a zone of saturated soil, with redox potentials as low as $-400 \mathrm{mV}$ (Mitsch \& Gosselink, 1986), and this is low enough to convert nitrogen, iron and sulphur to their reduced forms in groundwater passing through a saturated riparian zone. McClain et al. (1994) noted an increase in $\mathrm{Fe}^{2+}$ and ammonium in shallow groundwater passing through this zone. Therefore in hyporheic zones fed by deeper groundwaters, or those passing through riparian wetlands, there is a greater chance that reduced inorganic compounds will be concentrated enough to contribute to hyporheic productivity.

Sulphur is another major constituent of groundwaters, commonly occurring as sulphate in concentrations of more than $30 \mathrm{mg} \mathrm{L}^{-1}$ (Langmuir, 1997), and it could potentially play a significant role in hyporheic microbial dynamics. In waters with circumneutral $\mathrm{pH}$, sulphur will not occur in a reduced state unless the redox potential of the water is below $-150 \mathrm{mV}$ (Mitsch \& Gosselink, 1986). This would rarely occur in groundwaters feeding directly into the hyporheic zone, but groundwaters that pass through saturated soils in the near-stream zone may well become reducing enough to carry sulphide or other reduced forms. Sulphide-oxidizing bacteria can gain around five times more energy from $1 \mathrm{~mol}$ of substrate than nitrifying bacteria. Thus, considering the much higher concentrations of sulphur than nitrogen in groundwaters, sulphide-oxidizers have a much greater potential than nitrifiers to contribute to hyporheic productivity under the right conditions.

Where inflowing groundwaters remain aerobic, 
reduced sulphur compounds can still become available to bacteria through the reduction of sulphate in the anoxic basal layers of biofilms. This process is known to occur in the millimetres-thick microbial mats which coat bed surfaces of hot springs, estuaries, etc. (Paerl \& Pinckney, 1996). It also has been documented in the biofilm of an aerobic trickling filter (Kuhl \& Jorgensen, 1992), which is more similar to the biofilms occurring in hyporheic zones in that it was micrometres thick and exposed to a constant interstitial flow of oxygenated water; here oxidation of H2S accounted for $48 \%$ of total oxygen consumption. This suggests that the micrometres-thick epilithic biofilms within stream beds also may create suitable micro-environments, in which chemolithotrophic processes can play an important role in subsurface oxygen dynamics and might contribute significantly to hyporheic microbial production. However, the importance of biofilm micro-environments for chemolithotrophy has not yet been investigated in hyporheic sediments, which have much lower nutrient concentrations than trickling filters.

\section{Alternatives to oxygen respiration}

Decomposition of organic matter is more rapid and efficient using aerobic respiration, but anaerobic respiration using nitrate, ferric ions, sulphate or carbon dioxide as electron acceptors is possible when organic matter occurs in areas of low oxygen. Nitrate respiration (also termed denitrification) has been identified as an important process in anaerobic areas of the hyporheic zone (Triska, Duff \& Avanzino, 1993b). Nitrate for this respiration may be supplied by inflowing waters (Garca-Ruiz, Pattinson \& Whitton, 1998), but in many hyporheic zones, as in some other aquatic habitats (e.g. Seitzinger, 1994), in situ nitrification is likely to be a more important supply. Coupled nitrification - denitrification requires movement of nitrate from an aerobic zone (redox potential $>200 \mathrm{mV}$ ), where it is produced, to an anaerobic zone (redox potential < $200 \mathrm{mV}$; Stolp, 1993). This is believed to occur as water enters anaerobic pockets within the aerobic hyporheic zone (Triska et al., 1993b), but a much more efficient exchange is likely between surface and basal layers in the biofilm coating of sediment particles (Paerl \& Pinckney, 1996). This has been documented in aerobic trickling filters (Schramm et al., 1996) and in epilithic biofilms on the streambed surface (Nakajima, 1979, Ventullo \& Rowe, 1982), but not yet in the hyporheic zone. This dynamic would allow denitrification to occur throughout the hyporheic zone, and would explain our observation that total dissolved inorganic nitrogen decreased significantly along a flowline in an aerobic area of the hyporheic zone (R. G. Storey \& D. D. Williams, unpublished data).

As far as we can ascertain, the contribution of denitrification to total organic matter decomposition in stream sediments has been reported in only one study (Christensen et al., 1990), although in this study it was significant, accounting for $25-50 \%$ of total carbon mineralization within sediment cores. However, the importance of denitrification to hyporheic productivity and organic matter budgets in other streams can be calculated. Gottschalk (1986) provides some useful equations showing the relative amounts of nitrate and oxygen required to oxidize $1 \mathrm{~mol}$ glucose, and showing that bacteria derive nearly as much free energy (and hence productivity) when switching to nitrate respiration as when using oxygen respiration:

glucose $+6 \mathrm{O}_{2} \rightarrow 6 \mathrm{CO}_{2}+6 \mathrm{H}_{2} \mathrm{O} \Delta \mathrm{G}^{0^{\prime}}=-2870 \mathrm{~kJ}$

glucose $+4.8 \mathrm{NO}_{3}^{-}+4.8 \mathrm{H}^{+} \rightarrow$

$6 \mathrm{CO}_{2}+2.4 \mathrm{~N}_{2}+8.4 \mathrm{H}_{2} \mathrm{O} \Delta \mathrm{G}^{0^{\prime}}=-2669 \mathrm{~kJ}$

(where $\Delta \mathrm{G}^{0^{\prime}}$ is the free energy yield of the reaction.)

In order to use these equations, in situ rates of denitrification and aerobic respiration must be measured simultaneously. In situ denitrification rates have rarely been measured in stream sediments, and such studies are recommended in order to determine the role of denitrification in stream ecosystem dynamics.

Other forms of anaerobic respiration may be widespread in hyporheic zones, yet we know of only three reports. Jones et al. (1994, 1995b) measured methanogenesis and aerobic respiration in oxic sediments beneath a stream channel and in anoxic sediments beneath the stream bank. They found that methanogenesis represented all the respiration occurring in anoxic sediments, and even occurred in oxic sediments where it accounted for $0.3-0.6 \%$ of total respiration. Dahm, Carr \& Coleman (1991) also found methane a significant component of hyporheic sediments in a first-order Mexican stream, even in aerobic areas, implying intense carbonate respiration 
in the sediments. Carbonate is the least energetically favourable of the various electron acceptors (Brock et al., 1984), and in groundwater systems methanogenesis occurs after iron, manganese and sulphate respiration have lowered the redox potential to below -200 mV (Drever, 1982; Stolp, 1993). Therefore to discover that methanogenesis occurs in hyporheic zones implies that iron, sulphate and manganese respiration also can occur where the concentrations of these ions are great enough.

The occurrence of methanogenesis at low rates in oxygenated sediments suggests that there are either many small pockets of anaerobic sediments, or microenvironments in biofilms, with redox potentials below $-200 \mathrm{mV}$. In either case, sulphate, iron and manganese respiration, which do not require such low redox potentials as methanogenesis $(<-150 \mathrm{mV}$ for sulphate; Mitsch \& Gosselink, 1986), may occur at higher rates in oxygenated sediments than those found for methanogenesis. Our own observations of black deposits on metal discs left in aerobic stream sediments suggest that sulphate reduction may be occurring, and investigations are recommended into the role of this process in hyporheic dynamics.

\section{Fungi}

While diverse forms of metabolism are likely to occur in the hyporheic zone, the bulk of hyporheic productivity is likely to be based on aerobic decomposition of organic matter. Both bacteria and fungi are able to perform this, yet only one study has reported on the occurrence of fungi in the hyporheic zone (Barlocher \& Murdoch, 1989), and none have reported their distribution in hyporheic sediments.

In the study of Barlocher and Murdoch, fungi accounted for only $2 \%$ of the microbial biomass in the biofilm colonizing glass beads. However, fungi undoubtedly will be more abundant on the surfaces of organic particles. In a stream surface habitat, Sinsabaugh, Golladay \& Linkins (1991) found fungal biomass on wood to be 20-50 times higher than on glass surfaces. Fungal colonies on wood and leaf detritus are typically dense, their biomass often exceeding $15 \%$ of the total detrital mass, which is more than ten times that of bacteria (Gessner \& Chauvet, 1997). Fungi are more important than bacteria in the initial breakdown of POM, being the main decomposers of cell wall materials such as cellulose and lignin (Maltby, 1992), but they become less important in the latter stages of particulate breakdown, when particle size is reduced. Sinsabaugh \& Findlay (1995) found that the ratio of fungal to bacterial biomass dropped from $100: 1$ to $1: 1$ as particle size decreased from $4 \mathrm{~mm}$ to less than $0.63 \mu \mathrm{m}$.

Therefore fungal abundance, distribution and population dynamics in the hyporheic zone are likely to be linked to the timing and extent of coarse particulate organic matter (CPOM) inputs (Suberkropp, 1997). At present, POM inputs, storage and decomposition dynamics in bed sediments are poorly known (Maridet et al., 1997); an understanding of fungal abundances and dynamics in the hyporheic zone depends on a fuller understanding in this area.

However, the distribution of fungi is not limited entirely to the surfaces of coarse organic particles. Barlocher \& Murdoch (1989) showed that fungi are able to take advantage of close associations with bacteria in epilithic biofilms. Maltby (1992) also notes that some aquatic hyphomycetes are able to use DOM, and others can after DOM has flocculated or adsorbed to surfaces. Thus, fungi have been found even in deep subsurface aquifers (Gounot, 1994), and they may well occur throughout the hyporheic zone.

The importance of hyporheic fungi in stream ecosystem dynamics therefore is unknown at present. While they may be more productive than bacteria on detrital surfaces, their productivity per area of streambed still may be low, depending on the detrital content of the streambed (Suberkropp, 1997). However, if, as Jones (1997) suggests, 25-90\% of total organic matter storage occurs in the hyporheic zone, hyporheic fungi may play an important role in the mineralization of stream organic matter.

\section{Biofilms: making the story more complex}

The importance of biofilm dynamics in hyporheic microbial ecology has been mentioned in the above examples. In sediment habitats, almost all bacteria are attached to the sediment particles (Costerton \& Lappin-Scott, 1995) in highly structured assemblages. These assemblages consist of microcolonies of single bacterial taxa, each derived from a single colonizing cell, in a close spatial arrangement with microcolonies of different taxa. They are surrounded by a complex polysaccharide matrix which acts as a highly selective 
sieve, limiting the movement of gases, dissolved salts and macromolecules to and from the microcolonies (Paerl \& Pinckney, 1996). Because the matrix isolates microcolonies from the bulk water, biofilms allow metabolic activities which are quite different from those expected from the physicochemical parameters of the bulk water (Paerl \& Pinckney, 1996). Thus, as mentioned earlier, anaerobic activities are able to occur in aerobic habitats, and aerobic and anaerobic processes, such as sulphide oxidation and sulphate reduction, can occur in different layers of the same biofilm (Kuhl \& Jorgensen, 1992). Because the matrix maintains a close proximity between microcolonies of different bacterial types, sites of specific limited niches can be created. Thus bacterial types that require specific substrates, such as the methanogens which require $\mathrm{H} 2$, are able to grow because of close spatial arrangements with other bacterial types which produce these substrates (Korber et al., 1995).

Another important property of biofilms is the capture and concentration of nutrients and organic matter from the bulk water, which allows bacteria to grow in extremely oligotrophic conditions (Korber et al., 1995). Biofilms also can store organic compounds, retaining them in the presence of extracellular enzymes produced by the biofilm bacteria (Lock, 1993). This may allow biofilm bacteria to decompose non-labile compounds such as lignin, which would be unavailable as a food source to free-living cells.

Descriptions of hyporheic microbial ecology must incorporate these properties of biofilm dynamics. Kuhl \& Jorgensen (1992) have shown that entire cycles of sulphur and nitrogen may occur within a biofilm, so that large-scale measures of nutrient transformations may not reveal the diversity of microbial processes occurring within the habitat; yet Paerl \& Pinckney (1996) emphasize that measuring microscale processes is very important for obtaining realistic and representative macroscale fluxes.

\section{Spatial distributions}

Although biofilms may create micro-environments, allowing, for example, anaerobic processes in aerobic sediments, the physicochemical conditions of the interstitial water have been shown to determine the dominant processes occurring in various parts of the hyporheic zone. Dissolved oxygen, in particular, strongly influences the distribution of microbial processes (e.g. Triska et al., 1993b). Downwelling zones and subchannel sediments typically have higher oxygen levels than upwelling zones and bank sediments (Triska et al., 1993b; Jones et al., 1995a) because they have a higher proportion of surface water, and that water has spent less time in the subsurface. Therefore in downwelling zones and subchannel sediments, aerobic processes are favoured (Triska et al., 1993b) and amounts of labile organic matter (dissolved and particulate) are higher (Findlay et al., 1993), leading to higher bacterial densities and production (Hendricks, 1993).

Most field studies of hyporheic processes thus far have measured broad-scale patterns, with at most only two to three sampling points within a riffle study site. However, a few authors (e.g. Hendricks, 1993; Williams, 1993; Fraser, Williams \& Howard, 1996) have commented on the great heterogeneity of physicochemical parameters in hyporheic sediments. This arises partly because of local variations in flow patterns resulting from subsurface features such as clay lenses or large buried rocks (Brunke \& Gonser, 1997), which may create stagnant pockets. Also, local upwelling 'spikes' may bring groundwater into an otherwise surface water-dominated area (R.G. Storey \& D.D. Williams, unpublished data), thus creating a small pocket, only a metre or less wide, of anaerobic conditions, with colder or warmer temperatures, higher or lower inorganic nutrient content, etc. We have also observed local 'hotspots' with extremely high concentrations of DOC and nitrogen compounds (up to $5.5 \mathrm{mg} \mathrm{L}^{-1} \mathrm{DOC}$ and $8 \mathrm{mg} \mathrm{L}^{-1}$ total inorganic nitrogen against a background of $2.4 \mathrm{mg} \mathrm{L}^{-1} \mathrm{DOC}$ and $0.3 \mathrm{mg} \mathrm{L}^{-1}$ total inorganic nitrogen), less than $0.5 \mathrm{~m}$ wide, which do not appear to be related to any variations in flow. Whereas some of these hotspots appear only once in sampling programs, some persist for many months, and may change character over time, consuming or releasing DOC, becoming anaerobic, etc. These hotspots are believed to result from intense microbial activity, but the causes of this activity remain unclear.

While several studies have commented on heterogeneities within the hyporheic zone, none have yet compared the microbial types or processes within these pockets to those in the surrounding sediments. Nor have any investigated the importance of such heterogeneities to coupled microbial processes, such as nitrification-denitrification, which involve a 
series of steps requiring different habitat conditions. Completion of the denitrification process from organic nitrogen may be greatly enhanced by flow through the alternately aerobic and anaerobic conditions created by such pockets, and the overall flux of nitrogen from the system may be significantly increased. Finer-scale studies are therefore recommended of physicochemical patterns and microbial distributions in the hyporheic zone than have been conducted so far. As pockets of different physicochemical conditions can be less than $1 \mathrm{~m}$ wide, studies which are affected by, or which aim to characterize these heterogeneities need sampling points to be spaced on this scale.

\section{New technologies}

Recent progress in the understanding of biofilm dynamics and aquatic microbial ecology has been made possible by a number of powerful new techniques which allow in situ investigations of microbial processes and community structure. More thorough discussions of these techniques can be found in books and reviews, such as Kemp et al. (1993), Paul (1993), Revsbech (1994) and Costerton et al. (1995). However, a few of these techniques, which are particularly relevant to the questions in this discussion - determining the micro-organisms present, their spatial distributions and the types and rates of microbial activity in hyporheic biofilm communities - deserve mention here.

Determinations of structure and function in living biofilms have recently been made possible by combining new microscopic techniques with new types of fluorescent molecular probes, and the application of micro-electrodes to biofilms. Confocal scanning laser microscopy (CSLM) has allowed non-destructive, in situ analysis of living biofilms without the need for chemical fixation or embedding techniques (Costerton et al., 1995). Because chemical fixation is not required, CSLM can be used with indicators of metabolic functions or physicochemical conditions (see below) directly to observe the microscale relationships of bacteria to each other and to their environments. Confocal scanning laser microscopy also allows biofilms to be viewed on opaque surfaces, such as the mineral particles and detritus where they naturally occur, and new digital image analysis techniques allow the data to be viewed as optical thin sections in any dimension, without interference from out-offocus areas.

Fluorescent molecular probes are continually being developed as indicators of physicochemical conditions, metabolic activities and bacterial types. Existing probes, which indicate micro-environments of differing $\mathrm{pH}$, redox potential or electrochemical charge, can show whether microsites suitable for particular types of bacterial activity are available within a biofilm (Costerton et al., 1995). Probes showing sites where particular enzymes are active, or where particular metabolic products occur, can give more direct evidence of particular bacterial processes (McFeters et al., 1995). Most recently, fluorescent probes have been developed which hybridize with specific oligonucleotide sequences on the 16S rRNA of bacterial cells (Ramsing, Kuhl \& Jorgensen, 1993). These are used to identify particular bacterial types, being targeted as specifically as to a single bacterial strain or as broadly as to an entire functional group or a whole kingdom of bacteria. Therefore, locating the exact position of nitrifying and sulphate-reducing bacteria, for example, within a biofilm is now possible. 16S rRNA oligonucleotide probes are now being developed further to indicate the physiological status (such as nutrient limitation or other environmental stress) of bacterial cells (McFeters et al., 1995; Paerl \& Pinckney, 1996), and Poulsen, Ballard \& Stahl (1993) have used them to infer growth rates of sulphate-reducing bacteria in a biofilm.

These indicators of biofilm community structure are most powerful when combined with direct measurements of chemical concentrations and fluxes at known positions in the biofilm. Micro-electrodes are now available which measure concentrations of oxygen, $\mathrm{pH}$, sulphide, ammonia, nitrate and nitrous oxide (Kuhl \& Jorgensen, 1992; Schramm et al., 1996). With tips measuring only 2-50 $\mu \mathrm{m}$, these micro-electrodes make it possible to study microzonations of bacterial substrates and products on scales of less than $100 \mu \mathrm{m}$ (Kuhl \& Jorgensen, 1992). From concentration profiles of the various compounds, fluxes, and hence production rates, can be calculated, using Fick's first law of diffusion (Schramm et al., 1996).

Recent advances also have been made in macroscale measures of microbial processes. To answer questions regarding the role of various microbial processes in the hyporheic ecosystem requires measurement of in situ rates under in situ conditions. Studies of hypor- 
heic nitrogen dynamics to date have measured potential rates only (e.g. Triska et al., 1993a,b) or have used inhibition methods, which disrupt potentially important nitrification - denitrification coupling (e.g. Triska et al., 1993a,b). However, recently developed techniques using the nitrogen-stable isotope $15 \mathrm{~N}$ allow simultaneous measurement of several nitrogen transformations, including coupled and uncoupled processes, and are relatively easy to perform (Stepanauskas et al., 1996). In situ concentrations of nitrate are only slightly modified and the technique is suitable for use on intact sediment cores. An alternative for estimating in situ denitrification rates in cores is to measure evolution of nitrogen gas, which, when combined with measurements of oxygen consumption, can indicate the relative importance of oxygen and nitrate respiration (Seitzinger, 1994). Subsequent addition of nitrate or use of nitrification inhibitors can indicate the importance of coupled nitrification - denitrification. These techniques have been used successfully in wetland soils, and should be applicable to hyporheic sediments.

\section{Conclusions}

It is predicted that the hyporheic zone will be found to contain a much wider diversity of microbial types and microbial processes than has thus far been shown, or than might be expected from measurements of changes in interstitial water chemistry. The highly complex communities of interdependent bacterial types found in trickling filters are likely to occur similarly in hyporheic sediments, creating conditions which may permit a variety of anaerobic processes and processes requiring very specific substrates. It is therefore recommended that future work should examine a broad range of metabolic processes within hyporheic sediments, including oxidative and reductive transformations of sulphur compounds, iron, manganese, hydrogen and hydrocarbons, as well as nitrogen, and examine hyporheic biofilm communities for the presence of bacterial types associated with these transformations. To understand the interaction of these processes, spatial relationships between the bacterial types should be examined, both on the microscale within biofilms, and on the scale of the hyporheic zone.

Inorganic reduced compounds in groundwater are unlikely to be a major source of energy to hyporheic productivity, except if stream DOC concentrations are very low, or fertilizer inputs in the catchment are high. Where riparian wetlands lower the redox potential of shallow groundwaters there is a much greater possibility of significant chemolithotrophic productivity. Even where such productivity is low, chemolithotrophs may still occur in moderate abundance and may significantly affect hyporheic oxygen dynamics. To evaluate these predictions future studies should measure rates of chemolithotrophic and heterotrophic activity simultaneously. Studies that compare hyporheic zones receiving waters from different sources, particularly wetlands with very low redox potential or groundwaters high in a certain inorganic compound, may show how hyporheic systems differ in terms of their energy basis and oxygen dynamics.

Anaerobic respiration may be common in biofilms in aerobic sediments, although anaerobic metabolism clearly is still higher where interstitial dissolved oxygen concentration is lower. Anaerobic respiration yields only a little less energy than aerobic, and may account for a significant proportion of total organic matter oxidation in the hyporheic zone. Studies which measure in situ rates of aerobic and anaerobic respiration simultaneously may increase understanding of how hyporheic productivity and nutrient cycles vary under different oxygen conditions.

Hyporheic fungi have been little studied but are predicted to be as important in processing POM as their benthic counterparts. A significant proportion of stream organic matter is stored in the hyporheic zone, and hyporheic fungal decomposition could be an important pathway for organic matter mineralization in streams. Since relationships of fungal biomass and productivity to the changing properties of decomposing POC have already been described for the stream surface, hyporheic studies can answer many questions simply by describing the dynamics of detritus input timing of input events, movement of POC, changes in particle size with depth and time - in the hyporheic zone. Comparisons of fungal productivity to bacterial productivity in the hyporheic zone, and comparisons of hyporheic to surface fungal productivity per unit area would also increase understanding of the role of hyporheic fungi in the stream ecosystem.

Hyporheic protozoans and metazoans certainly rely on bacteria to make dissolved energy sources available as food, and probably benefit greatly from 
microbial preprocessing of detrital food. Thus hyporheic bacteria and fungi play a crucial role at the base of the interstitial foodweb.

\section{References}

Barlocher F. \& Murdoch J.H. (1989) Hyporheic biofilms: a potential food source for interstitial animals. Hydrobiologia, 184, 61-67.

Brock T.D., Smith D.W. \& Madigan M.T. (1984) Biology of Microorganisms, 4th edn. Prentice-Hall Inc., New Jersey.

Brunke M. \& Gonser T. (1997) The ecological significance of exchange processes between rivers and groundwater. Freshwater Biology, 37, 1-33.

Christensen P.B., Nielsen L.P., Sorensen J. \& Revsbech N.P. (1990) Denitrification in nitrate-rich streams: diurnal and seasonal variation related to benthic oxygen metabolism. Limnology and Oceanography, 35, 640-651.

Codd G.A. \& Kuenen J.G. (1987) Physiology and biochemistry of autotrophic bacteria. Microbial Growth on C1 Compounds (eds H. W. van Verseveld and J. A. Duine), pp. 9-20. Martinus Nijhoff Publishers, Dordrecht.

Costerton J.W. \& Lappin-Scott H. (1995) Introduction to microbial biofilms. Microbial Biofilms (eds H. LappinScott and J. W. Costerton), pp. 1-11. Cambridge University Press, Cambridge.

Costerton J.W., Lewandowski Z., Caldwell D.E., Korber D.R. \& Lappin-Scott H.M. (1995) Microbial biofilms. Annual Review of Microbiology, 49, 711-745.

Dahm C.N., Carr D.L. \& Coleman R.L. (1991) Anaerobic carbon cycling in stream ecosystems. Verhandlungen der Internationalen Vereinigung für Theoretische und Angewandte Limnologie, 24, 1600-1624.

Drever J.I. (1982) The Geochemistry of Natural Waters. Prentice-Hall Inc., Englewood Cliffs, New Jersey.

Fiebig D.M. \& Lock M.A. (1991) Immobilization of dissolved organic matter from groundwater discharging through the stream bed. Freshwater Biology, 26, 4555.

Findlay S. (1995). The importance of surface-subsurface exchange in stream ecosystems: The hyporheic zone. Limnology and Oceanography, 40, 159-164.

Findlay S., Strayer D., Goumbala C. \& Gould K. (1993) Metabolism of streamwater dissolved organic carbon in the shallow hyporheic zone. Limnology and Oceanography, 38, 1493-1499.

Fraser B.G., Williams D.D. \& Howard K.W.F. (1996) Monitoring biotic and abiotic processes across the hyporheic/groundwater interface. Hydrogeology Journal, 4, 36-50.
Garca-Ruiz R., Pattinson S.N. \& Whitton B.A. (1998) Denitrification in river sediments: relationship between process rate and properties of water and sediment. Freshwater Biology, 39, 467-476.

Gessner M.O. \& Chauvet E. (1997) Growth and production of aquatic hyphomycetes in decomposing leaf litter. Limnology and Oceanography, 42, 496-505.

Ghiorse W.C. (1984) Biology of iron- and manganesedepositing bacteria. Annual Review of Microbiology, 38, 515-550.

Gottschalk G. (1986) Bacterial Metabolism, 2nd edn. Springer-Verlag, New York.

Gounot A.M. (1994) Microbial ecology of groundwaters. Groundwater Ecology (eds J. Gibert, D. L. Danielopol and J. A. Stanford), pp. 189-215. Academic Press Inc., San Diego, CA.

Grimm N.B. \& Fisher S.G. (1984) Exchange between surface and interstitial water: implications for stream metabolism and nutrient cycling. Hydrobiologia, 111, 219-228.

Hackett G.H. \& Lehr J.H. (1985) Iron Bacteria Occurrence, Problems and Control Methods in Water Wells. National Water Well Association, Worthington, $\mathrm{OH}$.

Harvey J.W. \& Fuller C.C. (1998) Effect of enhanced manganese oxidation in the hyporheic zone on basinscale geochemical mass balance. Water Resources Research, 34, 623-636.

Hem J.D. (1989) Study and Interpretation of the Chemical Characteristics of Natural Water, 3rd edn. United States Government Printing Office, Washington D.C.

Hendricks S.P. (1993) Microbial ecology of the hyporheic zone: a perspective integrating hydrology and biology. Journal of the North American Benthological Society, 12, 70-78.

Hill A.R. (1990) Ground water flow paths in relation to nitrogen chemistry in the near-stream zone. Hydrobiologia, 206, 39-52.

Jones J.B. (1997) Benthic organic matter storage in streams: influence of detrital import and export, retention mechanisms and climate. Journal of the North American Benthological Society, 16, 109-119.

Jones J.B. Jr, Holmes R.M., Fisher S.G. \& Grimm N.B. (1994) Chemoautotrophic production and respiration in the hyporheic zone of a Sonoran Desert stream. Proceedings of the Second International Conference on Groundwater Ecology (eds J. A. Stanford and H. M. Valett), pp. 329-338. American Water Resources Association, Herndon, VA.

Jones J.B. Jr, Fisher S.G. \& Grimm N.B. (1995a) Nitrification in the hyporheic zone of a desert stream ecosystem. Journal of the North American Benthological Society, 14, 249-258.

Jones J.B. Jr, Holmes R.M., Fisher S.G., Grimm N.B. \& 
Greene D.M. (1995b) Methanogenesis in Arizona, USA dryland streams. Biogeochemistry, 31, 155-173.

Kaplan L.A. \& Newbold J.D. (1993) Biogeochemistry of dissolved organic carbon in streams. Aquatic Microbiology: an Ecological Approach (ed T. E. Ford), pp. 139-165. Blackwell Scientific Publications, Oxford.

Kaushik N.K., Robinson J.B., Stammers W.N. \& Whitely H.R. (1981) Aspects of nitrogen transport and transformation in headwater streams. Perspectives in Running Water Ecology (eds M. A. Lock and D. D. Williams), pp. 113-140. Plenum Press, New York.

Kemp P.F., Sherr B.F., Sherr E.B. \& Cole J.J. (1993) Handbook of Methods in Aquatic Microbial Ecology. Lewis Publishers, Boca Raton, FL.

Korber D.R., Lawrence J.R., Lappin-Scott H.M. \& Costerton J.W. (1995) Growth of micro-organisms on surfaces. Microbial Biofilms (eds H. M. Lappin-Scott and J. W. Costerton), pp. 15-45. Cambridge University Press, Cambridge.

Kuhl M. \& Jorgensen B.B. (1992) Microsensor measurements of sulfate reduction and sulfide oxidation in compact microbial communities of aerobic biofilms. Applied and Environmental Microbiology, 58, 1164-1174.

Langmuir D. (1997) Aqueous Environmental Chemistry. Prentice-Hall Inc., Upper Saddle River, NJ.

Lock M.A. (1993) Attached microbial communities in rivers. Aquatic Microbiology: an Ecological Approach (ed T. E. Ford), pp. 113-138. Blackwell Scientific Publications, Oxford.

McClain M.E., Richey J.E. \& Pimentel T.P. (1994) Groundwater nitrogen dynamics at the terrestrial-lotic interface of a small catchment in the Central Amazon Basin. Biogeochemistry, 27, 113-127.

McFeters G.A., Yu F.P., Pyle B.H. \& Stewart P.S. (1995) Physiological assessment of bacteria using fluorochromes. Journal of Microbiological Methods, 21, 1-13.

Maltby L. (1992) Heterotrophic microbes. The Rivers Handbook: Hydrological and Ecological Principles, vol. 1 (eds P. Calow and G. E. Petts), pp. 165-194. Blackwell Scientific Publications, Oxford.

Maridet L., Phillippe M., Wasson J.-G. \& Mathieu J. (1997) Seasonal dynamics and storage of particulate organic matter within bed sediment of three streams with contrasted riparian vegetation and morphology. Groundwater/Surface Water Ecotones: Biological and Hydrological Interactions and Management Options (eds J. Gibert, J. Mathieu and F. Fournier), pp. 68-74. Cambridge University Press, Cambridge.

Meybeck M. (1982) Carbon, nitrogen and phosphorus transport by world rivers. American Journal of Science, 282, 401-450.

Mitsch W.J. \& Gosselink J.G. (1986) Wetlands. Van Nostrand Reinhold Company Inc., New York.
Microbial ecology of the hyporheic zone

129

Moss B. (1988) Ecology of Fresh Waters: Man and Medium. Blackwell Scientific Publications, Oxford.

Nakajima T. (1979) Denitrification by the sessile microbial community of a poluted river. Hydrobiologia, 66, 57-64.

Paerl H.W. \& Pinckney J.L. (1996) A minireview of microbial consortia: their roles in aquatic production and biogeochemical cycling. Microbial Ecology, 31, 225247.

Paul J.H. (1993) The advances and limitations of methodology. Aquatic Microbiology: an Ecological Approach (ed T. E. Ford), pp. 15-46. Blackwell Scientific Publications, Oxford.

Poulsen L.K., Ballard G. \& Stahl D.A. (1993) Use of rRNA fluorescence in situ hybridisation for measuring the activity of single cells in young and established biofilms. Applied and Environmental Microbiology, 59, 1354-1360.

Pusch M. \& Schwoerbel J. (1994) Community respiration in hyporheic sediments of a mountain stream (Steina, Black Forest). Archiv für Hydrobiologie, 130, 35-52.

Ramsing N.B., Kuhl M. \& Jorgensen B.B. (1993) Distribution of sulfate-reducing bacteria, $\mathrm{O}_{2}$, and $\mathrm{H}_{2} \mathrm{~S}$ in photosynthetic biofilms determined by oligonucleotide probes and microelectrodes. Applied and Environmental Microbiology, 59, 3840-3849.

Revsbech N.P. (1994) Analysis of microbial mats by use of electrochemical microsensors: recent advances. Microbial Mats: Structure, Development and Environmental Significance (eds L. J. Stal and P. Caumette), pp. 149163. Springer, New York.

Schramm A., Larsen L.H., Revsbech N.P., Ramsing N.B., Amann R. \& Schleifer K.H. (1996) Structure and function of a nitrifying biofilm as determined by in situ hybridisation and the use of microelectrodes. Applied and Environmental Microbiology, 62, 4641-4647.

Seitzinger S.P. (1994) Linkages between organic matter mineralisation and denitrification in riparian wetlands. Biogeochemistry, 25, 19-39.

Sinsabaugh R.L. \& Findlay S. (1995) Microbial production, enzyme activity and carbon turnover in surface sediments of the Hudson River estuary. Microbial Ecology, 30, 127-141.

Sinsabaugh R.L., Golladay S.W. \& Linkins A.E. (1991) Comparison of epilithic and epixylic biofilm development in a boreal river. Freshwater Biology, 25, 179-187.

Stepanauskas R., Davidsson E.T. \& Leonardson L. (1996) Nitrogen transformations in wetland soil cores measured by $15 \mathrm{~N}$ isotope pairing and dilution at four infiltration rates. Applied and Environmental Microbiology, 62, 2345-2351.

Stolp H. (1993) Microbial Ecology: Organisms, Habitats, Activities. Cambridge University Press, Cambridge. 
130 R.G. Storey, R.R. Fulthorpe and D.D. Williams

Suberkropp K. (1997) Annual production of leaf-decaying fungi in a woodland stream. Freshwater Biology, 38, 169-178.

Triska F.J., Duff J.H. \& Avanzino R.J. (1993a) The role of water exchange between a stream channel and its hyporheic zone in nitrogen cycling at the terrestrialaquatic interface. Hydrobiologia, 251, 167-184.

Triska F.J., Duff J.H. \& Avanzino R.J. (1993b) Patterns of hydrological exchange and nutrient transformation in the hyporheic zone of a gravel-bottom stream: examining terrestrial-aquatic linkages. Freshwater Biology, 29, 259-274.

Triska F.J., Jackman A.P., Duff J.H. \& Avanzino R.J. (1994) Ammonium sorption to channel and riparian sediments: A transient storage pool for dissolved inorganic nitrogen. Biogeochemistry, 26, 67-83.

Ventullo R.M. \& Rowe J.J. (1982) Denitrification potential of epilithic communitties in a lotic environment. Current Microbiology, 7, 29-33.
Volk C.J., Volk C.B. \& Kaplan L.A. (1997) Chemical composition of biodegradable dissolved organic matter in streamwater. Limnology and Oceanography, 42, 39-44.

Wielinga B., Benner S., Brick C., Moore J. \& Gannon J. (1994) Geomicrobial profile through the hyporheic zone of a historic mining flood plain. Proceedings of the Second International Conference on Groundwater Ecology (eds J. A. Stanford and H. M. Valett), pp. 267-276. American Water Resources Association.

Williams D.D. (1993) Nutrient and flow vector dynamics at the hyporheic/groundwater interface and their effects on the interstitial fauna. Hydrobiologia, 251, 185-198.

Williams D.D. \& Hynes H.B.N. (1974) The occurrence of benthos deep in the substratum of a stream. Freshwater Biology, 4, 233-256.

(Manuscript accepted 17 August 1998) 